\title{
Laus på rogna
}

\author{
Ikke sjelden dukker det opp interessante ting mens man leter etter noe annet.
}

I Tidsskriftet anno 1940 kom jeg over en liten historie med tittelen Laus på rogna (1). Året var jo ellers preget av alvorlige begivenheter, men i utgaven som utkom 15. mai fant redaksjonen altså plass til denne kostelige historien.

«Laus på rogna» er et fiskeruttrykk som fortsatt lever. Det betyr rett og slett at fisken er gytemoden (2). Betydningen er helt konkret. Man skilte mellom fisk med fast rogn og fisk som var gytemoden, og i denne overgangen ble fisken «laus på rogna» og nedsatt i pris. Dette skjedde omkring midten av mars. Rognpartiet ble da solgt, og fiskerne fikk noen kroner mellom hendene. Dette ga grunnlag for en fest 25. mars, da rognsalget var avviklet. Denne festen ble kalt Den store brennevinsdagen (2).

Fiskeren i historien forteller at han burde skjønt at kona var «laus på rogna». Siktet han til at fødslene hadde gått fort - «utrulig snopt å ledig» - eller at kona hadde hatt korte svangerskap? Uansett er fortellingen et eksempel på at lokalkunnskap og dialektforståelse kan være avgjørende ferdigheter hos leger. Kjenner noen av leserne til at uttrykket «laus på rogna» har vært $\mathrm{i}$ bruk om mennesker?

\section{Hvem var forfatteren?}

Signaturen «H. A.» kan være Harald Arnesen (1862-1953). Han hadde en mangslungen medisinsk karriere. De siste årene av yrkeslivet var han asyldirektør flere steder, på Dikemark i 1920-årene. Historien vitner om en lege med forståelse for psykosomatiske problemstillinger.

Som ung lege var Arnesen distriktslege i Måsøy i Finnmark (den gang skrevet Maasø). Det var en hard tid, og da han kom dit i 1891, syntes han det var «fælt at tænke paa, at jeg her skulde ha mit hjem i flere aar» (3). Men etter som årene gikk følte han seg stadig mer hjemme, og «det var slet ikke med nogen egentlig lyst, jeg vaaren 1898 forlot distriktet for at dra sydover» (3).

I historien refererer legen til Den rettsmedisinske kommisjons uttalelse. Denne kommisjonen ble etablert i 1900, og et viktig tema i mange år var spørsmål om svangerskapsvarighet. I 1907 skrev kommisjonen en uttalelse om dette temaet og mente at fødsel av fullbåret barn kunne finne sted etter en svangerskapsvarighet av «blot

\section{«Laus på rogna».}

En fisker søkte meg, han hadde nervøs dyspepsi, ujevn søvn, var deprimert. Han hadde okonomiske vansker den senere tid, hadde noe trubbel med en svigersønn, og for $1 / 2$ års tid siden hadde han fått til nabo en kjent kranglemaker, som skapte ufred.

Jeg sa det andre ville nok rette seg, han fikk ta det med kristelig tålmod. Hvad naboen angikk var han selv for snill og fredelig, så naboen bare ble frekkere; ville han ikke gi seg med det gode, fikk han snakke alvorlig til ham og om nødvendig true med juling; etter mitt kjennskap til fyren satt hans mot bare i kjeften. Men er det ellers noe som trykker sinnet? spurte jeg.

Han så en stund på meg, og sa så: «Da var rart, Dokker skull spør slik. Jau, da e ein ting; som har kvilt på meg alle år, e he stendig båre tvil om den første glunten var min». - Han kom fra Lofotfiske, var bare hjemom ett døgn og drog så med dampbåten til Finnmark «å den ti, e kom heim var ho ret nokså langt på veg». Han oppgav meg dato for hjemmevær og for nedkomst. «E syntes, da var altfor knap ti, a e forhørt jormorn; ho sa, at først gangen e da noko serskilt for mange, noken går besett så lenge, å noken kommer overlag tileg. Ho loft, ho inkje skul nevn før nokon, at e bar tvil, å da he ho heldt. Men e kunn inkj ret tru ho; Dokker he vel sjøl videnskap om, kor kvinfolkan stendig heng ihop mot os manfolk. Ka Dokker trur om da?» Jeg regnet ut i almanakken og fant at det var like innpå den kortest tillatelige tid, og sa ham at selv om nedkomsten hadde vært 2 dager før, var det intet å si på det etter den rettsmed. kom.'s uttalelse. Det var morsomt å se lettelsen avspeile seg på ham. Den bøyede skikkelse ranket seg, det matte blikk ble livlig, den tunge og trege tale likeså, og smilende sa han: «Så da kan passér! Jau, alle hennar nedkomster he gåt utrulig snopt å ledig, så e børt jo for læng sea skjønt, at ho var laus på rogna».

Et halvt år etter var han hos meg for å få stelt på et sår og var da riktig kjekk, han pratet og lo da han fortalte om naboen. «E gjord net så Dokker befalt, e tok han ein kvell i skuldran å riste han godt, så tennan skrangle; han skjønt kor makta var, å e sa, at hvisåskjønt han inkj var nøgd med da, skull e tak han meir alvorsleg nest gang, han for med strekan sine. Å sea er han vorten så finsleg, at vi he inkj å sei på hans adfære».

$$
\text { H. } A \text {. }
$$

Faksimile fra Tidsskriftet 15. mai 1940 (1)

\section{5-240 dage efter stedfundet samleie» (4).}

Hvis forfatteren av denne teksten virkelig er Harald Arnesen, er det uklart når hendelsen kan ha funnet sted. Så vidt jeg kan se av hans biografi, arbeidet han ikke nordpå etter 1907. På den annen side er historien så god at det vel kan tenkes at han diktet litt på den.

\section{Erlend Hem}

erlend.hem@medisin.uio.no

Erlend Hem (f. 1970) er dr.med., fagsjef i Klinikk psykisk helse og avhengighet, Oslo universitetssykehus, og redaktør for Tidsskriftets språkspalte.
Litteratur

1. H. A. Laus på rogna. Tidsskr Nor Lægeforen 1940; 60: 430 .

2. Bottolfsen $\emptyset$. red. Nord-Norge i nær fortid. Oslo: Samlaget, 1986: 69. www.nb.no/nbsok/nb/ 2405a3bf9876fdb1fee8c2b664e5bee5.nbdigital? lang=no\#72 (24.1.2017).

3. Larsen $\emptyset$. red. Norges leger. Bd. 1. Oslo: Den norske lægeforening, 1996: 150-3. www.nb.no/nbsok/nb/ 7792a2ae04bb8081194fabd36b5c73eb?index= 1\#153 (24.1.2017).

4. Angaaende spørgsmaal om svangerskabsterminen. Den retsmedicinske kommisions beretning for aaret 1907. Kristiania: Nationaltrykkeriet, 1909. 